\title{
Synergistic effect of RHA and FCW in alkali- aggregate reaction mitigation
}

\author{
Ef eito sinérgico da CCA e do RCV na mitigação da reação \\ álcali agregado
}

\begin{tabular}{r}
\hline Saguida Gomes de Abreu \\
Sano Leopoldo - RS - Brasil \\
Sinos \\
São Leopoldo - RS - Brasil \\
Sinos \\
${ }^{1}$ Patrícia Guillante \\
${ }^{1}$ Universidade do Vale do Rio do
\end{tabular}

\author{
Patrícia Guillante \\ Aguida Gomes de Abreu \\ Marlova Piva Kulakowski \\ Maurício Mancio \\ Claudio de Souza Kazmierczak
}

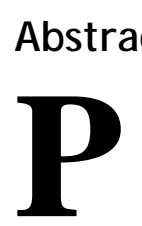

ozzolans rich in silica, such as Rice Husk Ash (RHA), contribute to compressive strength gain but at the same time might increase alkaliaggregate reaction (AAR) in mortar mixtures. Pozzolans that have aluminates, such as Fired Clay Brick Waste (FCW), can be efficient to mitigate AAR but tend to lead to a slower compressive strength development. The association of different types of pozzolans, however, may result in a synergistic effect, compensating individual deficiencies. This paper presents a study of mixtures containing RHA, FCW and these two materials combined, aiming to obtain benefits in the mechanical behavior and in the durability regarding AAR. A substitution rate of $20 \%$ Portland cement by pozzolanic material was used. Through accelerated AAR tests and compressive strength measurements, it was found that while RHA is considered harmful to AAR - even when using an innocuous aggregate - FCW presents benefits, also avoiding this deleterious effect when combined with RHA. The same occurs in the compressive strength development, where RHA compensates a small loss of compressive strength associated with the use of FWC alone.

Keywords: Rice Husk Ash. Fired Clay Brick Waste. Alkali-Aggregate Reaction.

\section{Resumo}

Pozolanas ricas em sílica, como a Cinza de Casca de Arroz (CCA), contribuem para o aumento da resistência à compressão, mas, ao mesmo tempo, podem contribuir para a ocorrência de reação álcali agregado (RAA). Por sua vez, as pozolanas que contêm aluminatos, como o Resíduo de Cerâmica Vermelha (RCV), podem ser eficientes para a mitigação da RAA, no entanto, há uma tendência à reduzir a velocidade de desenvolvimento da resistência à compressão. A assocoação de diferentes tipos de materiais pozolânicos, contudo, podem resultar em um efeito sinérgico, compensando deficiências individuais. Este artigo apresenta um estudo com CCA, RCV e o emprego combinado dos dois materiais, com o objetivo de obter melhorias tanto quanto ao comportamento mecânico quanto à durabilidade avaliada por RAA. Foi empregado um teor de substituição de $20 \%$ de cimento por material pozolânico. Os resultados do ensaio acelerado de $R A A$ indicaram que a CCA é prejudicial para a $R A A$, mesmo quando empregada com agregado não reativo. Já o RCV é capaz de mitigar a RAA, mesmo quando empregado em conjunto com a CCA. Para oss resultados de resistência à compressão, a CCA pode compensar uma pequena perda de resistência associada ao uso de RCV.

Recebido em 15/12/17

Palavras-chave: Cinza de Casca de Arroz. Resíduo de Cerâmica Vermelha. Reação Álcali Agregado. 


\section{Introduction}

Abundant in the south of Brazil, Rice Husk Ash (RHA) is a byproduct from the combustion process of rice husk as a source of heat generation required for the drying of rice grains (DAL MOLIN, 2007). RHA can present high pozzolanic activity depending on the combustion process, which varies depending mainly on the type of equipment used (grate, fluidized bed, open air), the temperature and time of exposure (POUEY, 2006). RHA obtained with combustion control and burning temperature between $500{ }^{\circ} \mathrm{C}$ and $600{ }^{\circ} \mathrm{C}$ shows amorphous characteristics. Higher temperatures lead to the formation of crystallized silica (cristoballite), with well-defined peaks of tridimite and cristoballite above $800{ }^{\circ} \mathrm{C}$ (HAMAD; KHATTAB, 1981). Considering that the amorphism grade of a material indicates its potential reactivity, the control of temperature in the calcination process is important. When evaluating the chemical contribution of RHA incorporated in cementitious matrices, several studies (SILVEIRA, 2007; MADANDOUST et al., 2011; ZAIN et al., 2011; JAMIL et al., 2013) have observed that typically there is an increase in the compressive strength over time in relation to the control samples. The benefits are associated with the formation of secondary $\mathrm{C}-\mathrm{S}-\mathrm{H}$, in addition to the filler effect, which promotes pore filling and pore refinement.

Fired Clay Brick Waste (FCW) is a calcined clay that has been studied in Brazil and in the world as an alternative pozzolanic material due to its widespread availability and satisfactory performance in concrete, both in the fresh and hardened states (GONÇALVES et al., 2009; PEREIRA-DE-OLIVEIRA; CASTRO-GOMES; SANTOS, 2012; ROJAS et al., 2014; KEPPERT et al., 2017). It has been shown that FCW can be used as a pozzolanic addition and be as effective as metakaolin, presenting good mechanical performance and durability (KEPPERT et al., 2017). Red ceramics are composed of clays, and these, in turn, are composed of clay minerals and may also contain other minerals such as quartz, feldspar, mica and hematite (KAZMIERCZAK, 2010). In Brazil, a mineralogical study carried out in the southeastern region of the country, indicated that the clays used for the production of red ceramics have kaolinite as the main mineral phase, followed by illite (SOUZA et al., 2005).

Several studies have evaluated the use of FCW as a pozzolanic material. Amorim, Pereira and Neves (2000) analyzed several samples and verified that specific surface area had an important role in the reactivity of the materials. Cordeiro and Désir (2010) verified that the burning temperature influences the reactivity of the FCW, as a function of the degree of crystalline disorder of the material. The results obtained by the authors confirm that the clays calcined at higher temperatures tend to have reduced pozzolanic activity. Gonçalves et al. (2009) evaluated the replacement of 10,20, 30 and $40 \%$ of cement by FCW and observed a reduction in the compressive strength in relation to the control mixture. The authors concluded that for contents above $20 \%$, as the amount of hydrates resulting from the pozzolanic reaction was likely insufficient to maintain a constant compressive strength, with extra FCW thus acting as a filler. The reaction capacity of pozzolans with calcium hydroxide contributes to concrete improvement, because the formation of secondary C-S-H promotes pore filling, enhanced durability in aggressive environments, higher compressive strength, reduction on heat of cement hydration, impermeability and reduction of environmental impacts. Improvements in electrical resistivity, reduction of efflorescence and mitigation of AAR, are also observed (PRISZKULNIK, 2005). Both FCW and RHA tend to improve the durability of concrete structures due to the formation of secondary C-S-H, which decreases permeability and enhances densification of the materials, making the mobility of alkalis and penetration of aggressive agents more difficult (DEMIR; YAPRAK; SIMSEK, 2011; ROJAS et al., 2014, SHARMA; SHARMA, 2018).

Therefore, the use of pozzolanic materials for AAR mitigation has been studied by different authors, such as Glasser (1992), Hasparyk (1999), Munhoz (2007), Chappex and Scrivener (2012a), Afshinnia and Rangaraju (2015), Le, Siewert and Ludwig (2015), Adorno et al. (2018), and others. Although the benefits attributed to pozzolans are related to calcium hydroxide consumption and secondary calcium silicate hydrate formation, there are still controversies found in the literature. This happens because there are pozzolans that present mitigating potential, while others, increase the expansions due to AAR.

Glasser (1992) attributes the efficiency of pozzolans in the reduction of the AAR expansions to four factors: the dilution of the alkali content due to the reduction of the clinker factor; the removal of the alkalis from the concrete pores through the formation of C-S-H; the reduction of permeability that inhibits the migration of the alkalis to react with the reactive minerals of the aggregate; and, finally, the reduction of $\mathrm{pH}$. However, Chappex and Scrivener (2012b) believe that the main mitigation factor is associated to the chemical composition of 
the materials, since pozzolanic materials rich in alumina are able to reduce the dissolution of the amorphous/disordered silica present in the aggregate, including in high $\mathrm{pH}$ solutions. The condition presented by the aforementioned authors is based on the adsorption of the alumina on the reactive silica surface of the aggregate, forming a type of barrier, preventing the amorphous silica in the aggregate from the contact with the alkalis from pore solution.

Turanli, Bektas and Monteiro (2003) evaluated the effect of FCW on AAR mitigation and observed reductions in expansion in relation to the cementonly sample and a slight decrease in reaction start time. However, over time the material lost its effectiveness, possibly by the formation of AAR products. When replacing 10, 25 and $50 \%$ of Portland cement by FCW, Afshinnia and Poursaee (2015) observed a reduction of the expansions by 31,67 and 95\%, respectively, in relation to the control sample. The observed benefits are associated to the chemical and physical properties of the material, which promote pozzolanic reactions that limit the mobilization of alkalis in the concrete. However, as previously reported by Chappex and Scrivener (2012b), it is believed that the significant effect of FCW in the AAR mitigation seems to be associated mainly to the alumina content present in this material.

Pozzolanic materials composed basically of silica, such as silica fume and rice husk ash, generally do not perform well when it comes to the AAR mitigation. Silveira (2007) studied different RHA contents $(12.5,25$ and $50 \%)$ by the C-1260 (AMERICAN..., 2014) accelerated test. Depending of the type of aggregate, the expansion reactions, regardless of the RHA content, exceeded the expansion reactions of the reference sample. At the end of the tests, an analysis of the microstructure of the mortar bars was carried out, and it was verified that the samples containing 50\% RHA presented particle agglomerates, which can induce AlkaliSilica Reaction (ASR). Although the 50\% RHA samples presented smaller expansion than the $25 \%$ RHA bars, it is possible that this reduction is associated to the reduction of the cement consumption and, consequently, the smaller quantity of alkalis available to react with the reactive aggregates.

Cyr, Rivard and Abrecque (2009) explain that a material containing silica can act as a pozzolanic material or as a reactive aggregate, depending of the size of the particles (or clusters). Thus, the effect of particle size and specific surface area is significant, so that a reactive aggregate of high fineness can become a pozzolanic material and a cluster of pozzolanic material can act as a reactive aggregate.
On the other hand, Le, Siewert and Ludwig (2015), when studying the RHA with three particle sizes $(5.7 \mu \mathrm{m}, 7.7 \mu \mathrm{m}$ and $15.6 \mu \mathrm{m})$ concluded that smaller particle sizes led to reduced expansion, because a more intense pozzolanic reaction occurs, which absorbs more alkaline ions and refines the pore structure. The same researchers studied the effect of RHA with an innocuous aggregate and verified that the samples produced with RHA generated expansions, even surpassing the control sample, in proportion to the particle size of the material, that is, the coarser the particle, the greater the expansion.

When replacing 10, 20, 30 and 40\% Portland cement by RHA, Abbas, Kazmi and Munir (2017) observed reductions in expansion as the substitution rate was increased, compared to the control sample, although the expansions still exceeded the limit of C-1260 (AMERICAN..., 2014). It is possible that the reduced expansion observed is related to the fact that the RHA used in this research presents approximately $6 \%$ of $\mathrm{Al}_{2} \mathrm{O}_{3}$, which is uncommon for this type of material, besides the reduction of cement consumption.

Adorno et al. (2018) evaluated the effect of $10 \%$ Portland cement replacement by FCW, RHA and limestone filler. They observed that between the control sample and the limestone filler there was no significant difference in the expansion reactions over time. However, the samples containing FCW and RHA exceeded the expansions of control samples, and the RHA showed, at 30 days, expansion about three times higher. It should be noted that the axial compressive strength of the FCW sample was lower than that of the control sample; by the mechanical test, the FCW sample also did not reach the pozzolan activity index limit.

The present study investigates the individual and combined effects of a siliceous pozzolanic material (RHA) and an aluminosilicate (FCW), using a reactive and an innocuous aggregate, in order to evaluate the synergistic effect of the RHA and the FCW in the AAR, as well as its effect in axial compressive strength.

\section{Materials and methods}

\section{Materials}

The cement used was a Portland Cement type V High Early Strength. The choice of the type of cement is due to its low mineral admixture content, which allows the monitoring of the effects of FCW, RHA and the combination of these two materials, in the AAR.

FCW was originated from ceramic blocks collected in a same production batch, in the city of Arroio do 
Meio, RS. The blocks have a monitored firing temperature, through sensors and controllers during the period of their firing, so that the average firing temperature of the blocks was between 700 and $750^{\circ} \mathrm{C}$. The beneficiation of FCW in powder form was carried out in three stages of comminution, including crushing and milling. Initially, the waste was subjected to a jaw crusher, after which the ceramic fragments underwent the first milling process in a roller mill. After this first milling, the calcined clay went through a more refined grinding process, performed with the aid of a ball mill.

The RHA comes from a same batch, originated from the biomass burning in a fluidized bed furnace of an energy generating company, located in the city of Alegrete, RS.

Two types of aggregates, collected in different quarries, were used. The aggregate considered innocuous comes from a quarry located in the city of Triunfo, RS, identified in this study as Aggregate Villa Rica (AVR). The aggregate with reactive potential, was collected in a quarry in the city of Flores da Cunha, RS, identified as Aggregate Flores da Cunha (AFC).

Through petrographic analysis, it was verified that the AVR comes from a rock that presents in its composition plagioclase (60\%) and clinopyroxenes (35\%). Moreover, the presence of secondary minerals resulting from the hydrothermal hydration or late magmatic processes was verified. However, although these secondary minerals have been found, the rock did not change its textural and structural characteristics, presenting itself complete and free of fractures. Based on the mineralogical composition and the textural characteristics, the rock was classified as a basalt.

The AFC, also through petrographic analysis, was classified as a dacite, due to the main mineralogical constituents (plagioclase - 67\%, quartz - 15\% and clinopyroxene - 15\%). Vitreous domains were found, which are rich in amorphous silica, alkali feldspars, and devitrification products, indicating the possible reactive potential of the rock. The vitreous residues and the products of devitrification found in the matrix represent the spherulite intergrowths, the mesostasis, the micrographic and quartz domains. The micrographic domains correspond to the intergrowths between quartz and feldspar, that form a mesostasis, indicating the siliceous nature and the fast cooling of the magma, since a great amount of quartz is present.

\section{Material's characterization}

\section{Chemical characterization}

Cement and pozzolanic materials were characterized chemically using X-Ray Fluorescence (XRF) by energy dispersion. This test uses a non-destructive technique that quantitatively and qualitatively determines the elements that compose the material in the form of oxides.

\section{Physical characterization}

The physical characterization included specific surface area and particle size distribution tests. The specific surface area of the cement and the pozzolanic materials were determined by the BET nitrogen adsorption method. The samples were previously oven dried at $105 \pm 5{ }^{\circ} \mathrm{C}$ and treated by heating and evacuation in Micromeritics VacPrep 061 equipment to remove contaminants. After preparation, the samples were analyzed using nitrogen as adsorbate and the equipment used was the Micromeritics, model TriStar II Plus. Materials particle size distributions were obtained by the laser diffractometry by the wet method, using ultrasound for particles dispersion. Since the mortar production for AAR tests used no superplasticizer admixture to disperse the pozzolanic materials, the sample preparation for laser diffractometry tests also did not employ a deflocculating agent, as sodium hexametaphosphate, to have a similar condition in both tests. The samples of RHA and FCW were prepared with water and external ultrasound was used for only 20 seconds.

\section{Mineralogical characterization}

The mineralogy of FCW and RHA was determined using X-ray Diffraction (XRD). The diffractograms were interpreted according to the database “Crystallography Open Database”, based on the information contained in scientific papers and on the XRF test.

\section{Morphology}

The qualitative evaluation of the size and morphology of FCW particles was based on micrographs obtained by scanning electron microscopy (SEM) (EVO MA15, Zeiss).

\section{Pozzolanic activity}

The pozzolanic activity of the RHA, the FCW and blended materials was measured using the test method described in NBR 5752 (ABNT, 2014), which evaluates the performance of pozzolanic materials with Portland cement at 28 days. For this procedure, CP II-F-32 and the normal sand from the 
Technological Research Institute (IPT), were used. The consistency of the mortars was adjusted, based on the consistency of the reference sample $\pm 10 \mathrm{~mm}$, using a polycarboxylate superplasticizer admixture.

\section{Accelerated method for testing the potential alkali reactivity of aggregates}

In order to evaluate the aggregates potential for AAR, and to complement the petrographic analysis, the C-1260 (AMERICAN..., 2014) mortar bars accelerated test was used. This method consists in monitoring the dimensional variation of $25 \mathrm{~mm} \times 25$ $\mathrm{mm} \times 280 \mathrm{~mm}$ mortar bars immersed in an alkaline solution of sodium hydroxide, with a concentration of $1 \mathrm{~N}$, at $80^{\circ} \mathrm{C}$ for a period of 28 days. The cementaggregate ratio was $1: 2.25$ and the water/cement ratio was 0.47 .

The mortar bars were fabricated in triple prismatic steel molds, with a fastening system composed of stainless steel bolts and pins, which enables the measurement of length using an extensometer with length gauge.

The expansion of the mortar bars was obtained through measurements at different test ages. Intermediate and main measures were carried out at the ages of 14 and 28 days after immersion in $\mathrm{NaOH}$ solution, respectively. C-1260 (AMERICAN..., 2014) states that expansions smaller than $0.10 \%$ at 16 days post-casting exhibit innocuous aggregate behavior, while expansions above $0.20 \%$ at 16 days post-casting are indicative of reactive aggregate. Expansions between $0.10 \%$ and $0.20 \%$ indicate that the aggregate is potentially reactive, and the test should be extended to the age of 30 days after casting.

\section{Evaluation of the efficiency of pozzolans to mitigate AAR}

The effect of FCW, RHA and the blended materials, in the AAR was evaluated using the C-1567 (AMERICAN..., 2013) test method, which is a standard test used to determine the potential for mitigation of mineral additions. Once the method is accelerated, it allows obtaining results at 14 days of testing. Similarly to the method presented in the previous item, mortar bars were fabricated and immersed in $1 \mathrm{~N} \mathrm{NaOH}$ solution at $80^{\circ} \mathrm{C}$ for a period of 14 days. However, the test was continued to the age of 28 days after immersion for the sake of comparison.

Portland cement was replaced by 20\% RHA, 20\% FCW and 20\% RHA + FCW (by volume), maintaining fixed the water/cement ratio of 0.47 , and cement-aggregate ratio of 1:2.25. C-1567 (AMERICAN..., 2013) specifies that expansions below $0.10 \%$ at 14 days after immersion are considered acceptable and thus, pozzolanic materials tend to have a low risk of deleterious expansion. Expansions above $0.10 \%$ at 14 days after immersion indicate that the materials generate potentially deleterious expansions.

\section{Axial compressive strength}

The axial compressive strength of the mortars was evaluated by adapting the NBR 7215 (ABNT, 1996) test method, to determine the compressive strength of Portland cement and mineral admixtures. In this study, normal sand was replaced by a potentially reactive aggregate, in this case, the AFC. Six cylindrical specimens of $50 \mathrm{~mm}$ diameter and 100 $\mathrm{mm}$ height were prepared for each mixture for the ages of 7, 28 and 63 days.

\section{Results and discussion}

\section{Materials characterization}

Table 1 shows the chemical composition of cement, RHA and FCW. It can be verified that the pozzolanic materials are different from each other: while RHA is basically composed of silica, the FCW presents, besides silica, considerable amounts of alumina and iron.

Figure 1 shows the particle size distribution curves of the cement, RHA and FCW. The Main characteristics of particle size are presented in Table 2. It can be verified that the cement had a mean particle diameter of $17.07 \mu \mathrm{m}$, the RHA of $9.38 \mu \mathrm{m}$, and the FCW had particles with a mean diameter of $53.36 \mu \mathrm{m}$. Possibly, the large particle diameter observed in the FCW is due the presence of particle clusters and its beneficiation and milling process.

The characterized specific surface area for the Cement is $4.540 \mathrm{~cm}^{2} / \mathrm{g}$; for the RHA is 11.517 $\mathrm{cm}^{2} / \mathrm{g}$; and for FCW is $40.463 \mathrm{~cm}^{2} / \mathrm{g}$. It can be observed that the FCW has a very high specific surface area compared to the RHA, about 3.5 times greater. Taking in account that the FCW showed a high mean particle diameter, its higher specific surface area could be explained by the inherent porosity of fired clay materials, as well by particle form.

In order to clarify the discrepancy around mean diameter and specific surface area, a SEM analysis of FCW was carried out (Figure 2). The analysis revealed the presence of large particles and significant amount of particles below $1 \mu \mathrm{m}$ in diameter. Moreover, the surface of grains was shown to be rather rough, often with masses of platelet-shaped particles. These masses may explain the grain size distribution observed and the presence 
of small particles. In addition, the rough surface of particles may be responsible for the high specific surface area of the material.

The mineralogical characterization was performed using XRD and Figure 3 shows the RHA and FCW diffractograms.

Through the results of the XRD test, it was possible to verify that the RHA presented crystalline peaks of silica in the form of quartz and cristoballite. The minerals found may be associated with the temperature and combustion process, since the rice husk presents high silica content. The enlarged area with the baseline detachment, observed between the angles $15^{\circ}$ and $30^{\circ}$, characterizes a clear amorphous halo in the material, which may be an indicator of its pozzolanic reactivity.

Figure 3(b) shows that the FCW also presented crystalline peaks of silica in the form of quartz and cristobalite, as well as crystalline peaks of microcline, muscovite (belonging to the silicate class) and hematite (responsible for the red-orange color). However, a baseline detachment was not observed.

Table 1 - Chemical composition of the cement and pozzolans

\begin{tabular}{c|c|c|c}
\hline Parameter & Cement (\%) & RHA (\%) & FCW (\%) \\
\hline $\mathrm{SiO}_{2}$ & 14.89 & 94.99 & 59.04 \\
$\mathrm{Al}_{2} 0_{3}$ & 3.50 & 0.18 & 18.23 \\
$\mathrm{Fe}_{2} \mathrm{O}_{3}$ & 2.41 & 0.06 & 14.45 \\
$\mathrm{CaO}$ & 57.26 & 0.33 & 0.81 \\
$\mathrm{MgO}$ & 3.20 & 0.01 & 0.81 \\
$\mathrm{SO}_{3}$ & 2.17 & 0.57 & $\mathrm{ND}$ \\
$\mathrm{Na}_{2} \mathrm{O}$ & 1.16 & $\mathrm{ND}$ & 0.50 \\
$\mathrm{~K}_{2} \mathrm{O}$ & 0.74 & 1.01 & 1.23 \\
$\mathrm{SrO}$ & 0.24 & $\mathrm{ND}$ & $\mathrm{ND}$ \\
$\mathrm{TiO}_{2}$ & 0.20 & 0.01 & 2.32 \\
$\mathrm{P}_{2} \mathrm{O}_{5}$ & 0.06 & 0.10 & 0.19 \\
$\mathrm{MnO}$ & 0.04 & 0.20 & 0.19 \\
$\mathrm{ZnO}$ & 0.02 & ND & ND \\
$\mathrm{Cr}_{2} \mathrm{O}_{3}$ & 0.01 & ND & ND \\
$\mathrm{L.O} . \mathrm{I}$ & 2.99 & 2.12 & 2.54 \\
\hline
\end{tabular}

Note: ND - Not Determined.

Figure 1 - Particle distribution curves of the cement, RHA and FCW

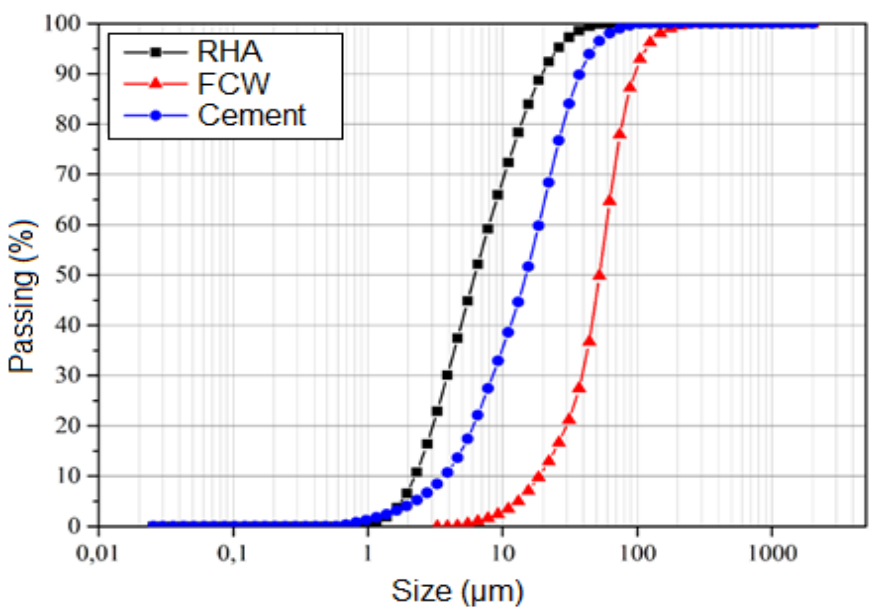

Table 2 - Chemical composition of the cement and pozzolans

\begin{tabular}{c|l|l|l}
\hline Characteristic & Cement $(\boldsymbol{\mu m})$ & RHA $(\boldsymbol{\mu m})$ & FCW $(\boldsymbol{\mu m})$ \\
\hline Diameter $<10 \%$ & 3.70 & 2.38 & 18.77 \\
Diameter $<50 \%$ & 14.97 & 7.04 & 52.43 \\
Diameter $<95 \%$ & 46.84 & 28.7 & 115.20 \\
Mean Diameter & 17.07 & 9.38 & 53.36 \\
\hline
\end{tabular}


Figure 2 - SEM Micrographs of FCW: (a) 3,500x and (b) 65,000x
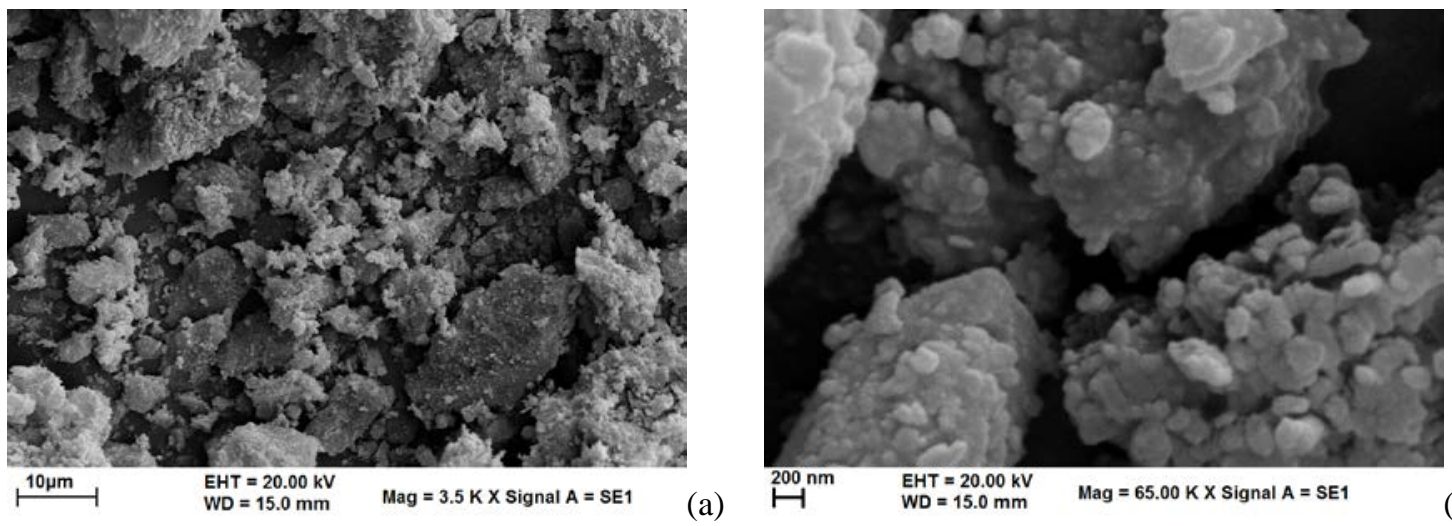

Figure 3 - XRD Diffractogram: (a) RHA and (b) FCW

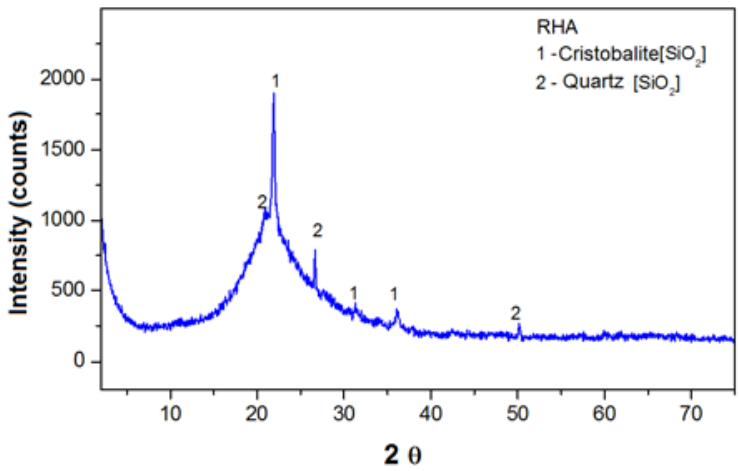

(a)

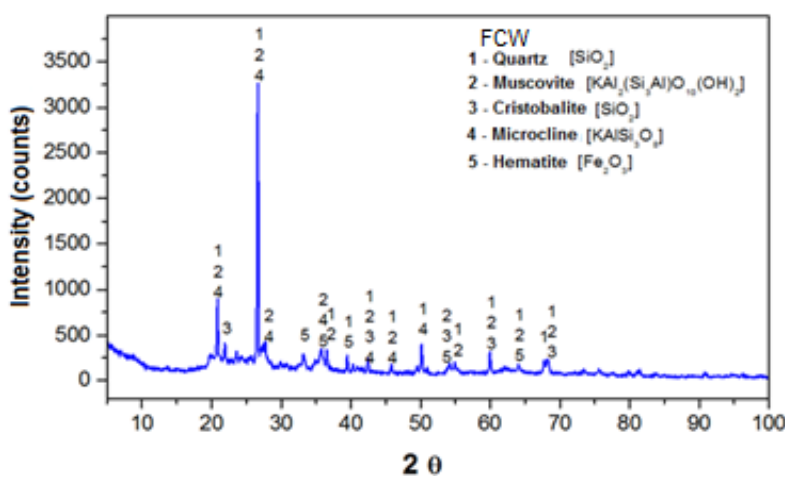

(b)

The pozzolanic activity of RHA, FCW and both materials combined is shown in Figure 4.

It can be observed that the sum $\mathrm{SiO}_{2}+\mathrm{Al}_{2} \mathrm{O}_{3}+$ $\mathrm{Fe}_{2} \mathrm{O}_{3}$ of $95.23 \%$ (Table 1) of the total composition is much higher than the $50 \%$ minimum value required by NBR 12653 (ABNT, 2014) for a pozzolanic material class $E$, which is the RHA classification. The pozzolanic activity of the RHA was $131 \%$, obtained in relation to the control mixture, as shown in Figure 4. This number represents $41 \%$ more than the minimum required for a pozzolan class $\mathrm{E}$, of $90 \%$.

The FCW is classified as a pozzolan class $\mathrm{N}$, according to NBR 12653 (ABNT, 2014). Through the analysis of the chemical characterization, it is observed that the sum $\mathrm{SiO}_{2}+\mathrm{Al}_{2} \mathrm{O}_{3}+\mathrm{Fe}_{2} \mathrm{O}_{3}$ of $91.72 \%$ of the total composition is higher than $70 \%$, the minimum value required by the aforementioned standard for this type of pozzolan. The FCW had a pozzolanic activity of $112 \%$, while the minimum required for pozzolanic material of class $\mathrm{N}$ is $90 \%$.

The pozzolanic activity of the combination RHA+FCW was also evaluated, and the value obtained was $123 \%$. Although it is not possible to

classify this combination, the minimum limit required for any class of pozzolanic material is $90 \%$. Therefore, it is verified that the combination RHA+FCW also meets this specification.

It can be observed that the sum $\mathrm{SiO}_{2}+\mathrm{Al}_{2} \mathrm{O}_{3}+$ $\mathrm{Fe}_{2} \mathrm{O}_{3}$ of $95.23 \%$ (Table 1 ) of the total composition is much higher than the $50 \%$ minimum value required by NBR 12653 (ABNT, 2014) for a pozzolanic material class $E$, which is the RHA classification. The pozzolanic activity of the RHA was $131 \%$, obtained in relation to the control mixture, as shown in Figure 4. This number represents $41 \%$ more than the minimum required for a pozzolan class E, of $90 \%$.

The FCW is classified as a pozzolan class $\mathrm{N}$, according to NBR 12653 (ABNT, 2014). Through the analysis of the chemical characterization, it is observed that the sum $\mathrm{SiO}_{2}+\mathrm{Al}_{2} \mathrm{O}_{3}+\mathrm{Fe}_{2} \mathrm{O}_{3}$ of $91.72 \%$ of the total composition is higher than $70 \%$, the minimum value required by the aforementioned standard for this type of pozzolan. The FCW had a pozzolanic activity of $112 \%$, while the minimum required for pozzolanic material of class $\mathrm{N}$ is $90 \%$. 
Figure 4 - Pozzolanic activity of the RHA, FCW and the combination RHA+FCW

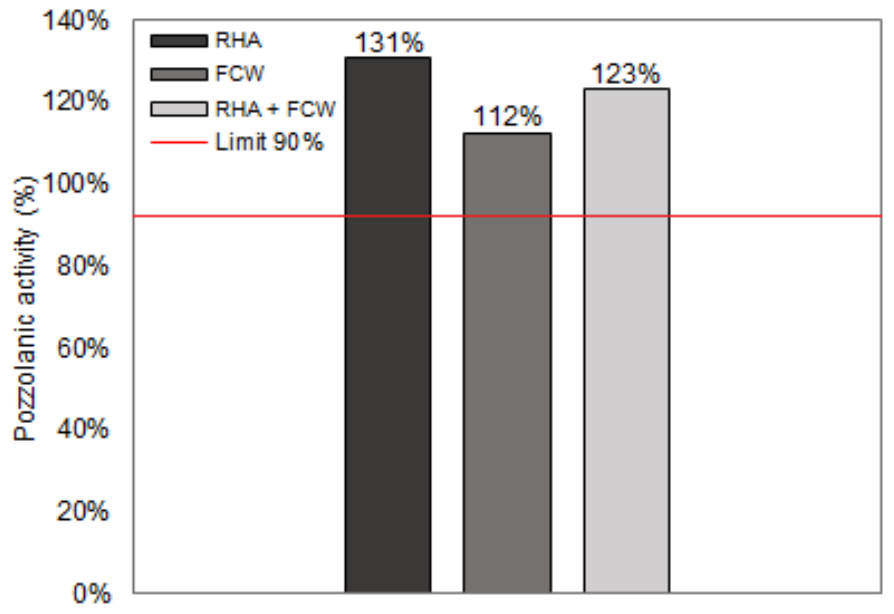

The pozzolanic activity of the combination RHA+FCW was also evaluated, and the value obtained was $123 \%$. Although it is not possible to classify this combination, the minimum limit required for any class of pozzolanic material is $90 \%$. Therefore, it is verified that the combination RHA+FCW also meets this specification.

\section{Reactive potential of aggregate}

The evolution of the expansion over time of the samples made with the two types of aggregates (AFC and AVR) is presented in the graph of Figure 5. These values represent the average of the three mortar bars.

It is verified that the AFC aggregate presented a linear growth over time, reaching the first limit of expansion at 10 days, with $0.13 \%$. At 14 days after immersion, it presented expansion of $0.17 \%$, remaining within the limits established by C-1260 (AMERICAN..., 2014). However, due to the possible reactivity of the aggregate, the test was continued until the age of 28 days, as recommended by standard. At this age, the sample showed expansion of $0.22 \%$, evidencing its reactivity.

The AVR aggregate, until 10 days, showed constant expansion of $0.01 \%$, and at 14 days, the expansion observed was $0.02 \%$. Although the aggregate remained below the $0.10 \%$ limit at 14 days after immersion in solution, the test was proceeded to 28 days, with a final expansion observed of $0.08 \%$.

The results verified by the accelerated method of expansion of the mortar bars confirmed the evidence presented in the petrographic analysis, based on the composition of the rocks tested. Thus, considering both the petrographic analysis and the accelerated expansion test, it is concluded that the AVR is classified as an innocuous aggregate, whereas the AFC is classified as a potentially reactive aggregate. The first one does not present risks to civil construction, being able to be used in works in general. However, in order to use the AFC, preventive measures are required, such as the use of pozzolanic materials and/or cements with low alkali content, to avoid occurrences of alkali-aggregate reaction.

\section{Efficiency of pozzolans in mitigating alkali-silica reaction}

Figure 6 shows the average expansions obtained with the pozzolanic materials and the aggregate AFC. Due to the small variability between samples of each mixture, it was not possible to plot the error bars in the graphs, therefore Table 3 shows the standard deviation for the three specimens produced for each mixture.

Samples containing $20 \%$ RHA had $0.10 \%$ of expansion at 14 days after immersion in solution, which is still within the expansion limit allowed by C-1567 (AMERICAN..., 2013) for this age. The same behavior was observed in the growth of the RHA expansions during the entire execution of the test, exceeding the expansion limit at the end of the test with an average value of $0.18 \%$. It is also noted that although there was expansion, the mortars fabricated with RHA presented reduced expansions when compared to the reference samples. Even though the expansion did not present very large values, the mortar bars containing RHA exhibited several microcracks in their surfaces, compromising their integrity.

The composite samples with 20\% FCW showed expansion of only $0.03 \%$ at 14 days of test, remaining below the limit of $0.10 \%$ established by C-1567 (AMERICAN..., 2013) during the entire period. The content of $20 \%$ cement substitution by FCW proved to be quite effective, even at the most 
advanced ages, reaching a maximum of $0.05 \%$ expansion at 28 days of testing. In this way, the FCW promoted reduction of the expansions by $77.3 \%$ in relation to the control sample. It can also be observed that the linear trend of FCW expansion, over time, is significantly lower than the reference sample. These results are similar to those presented by Afshinnia and Poursaee (2015), who verified a $67 \%$ reduction in sample expansions containing 25\% FCW. Differently than the RHA samples, samples tested with FCW did not show any changes in their surfaces, such as microcracks or gel bleeding.

Also, according to Figure 6, it can be observed that samples containing $10 \%$ RHA $+10 \%$ FCW remained below the expansion limit specified in C1567 (AMERICAN..., 2013), showing an expansion of $0.03 \%$ at 14 days. It is possible to observe a similarity between the expansion values obtained from the combination RHA + FCW and
FCW-only, in addition to the same trend of expansion behavior. At the end of the test, the samples containing 10\% RHA $+10 \%$ FCW reached an average expansion of $0.07 \%$, remaining below the limit established by the aforementioned standard. Similar to the samples containing FCW, those combined with RHA + FCW also did not present microcracks or gel exudation on their surfaces.

All the samples evaluated can be considered acceptable because their percentages of expansion remained within the limit of $0.10 \%$ established by C-1567 (AMERICAN..., 2013) at 14 days. Thus, according to this standard, they tend to have low risk of deleterious expansions. Again, this evaluation is based on the limiting percentage of expansion at the age of 14 days of testing. It should be noted, however, that the samples with RHA exceeded the limit of expansion at the measurements performed after 20 days of testing.

Figure 5 - Expansion of the mortar bars with aggregate AFC and AVR.

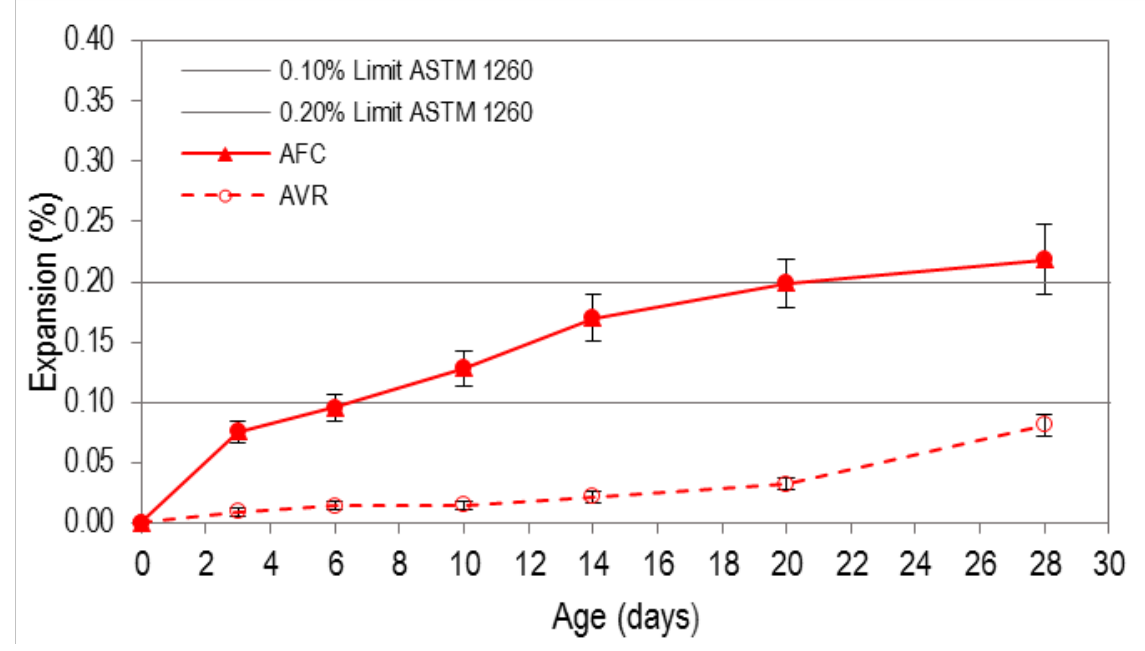

Figure 6 - Expansions of the mortar bars fabricated with pozzolans and reactive aggregate AFC

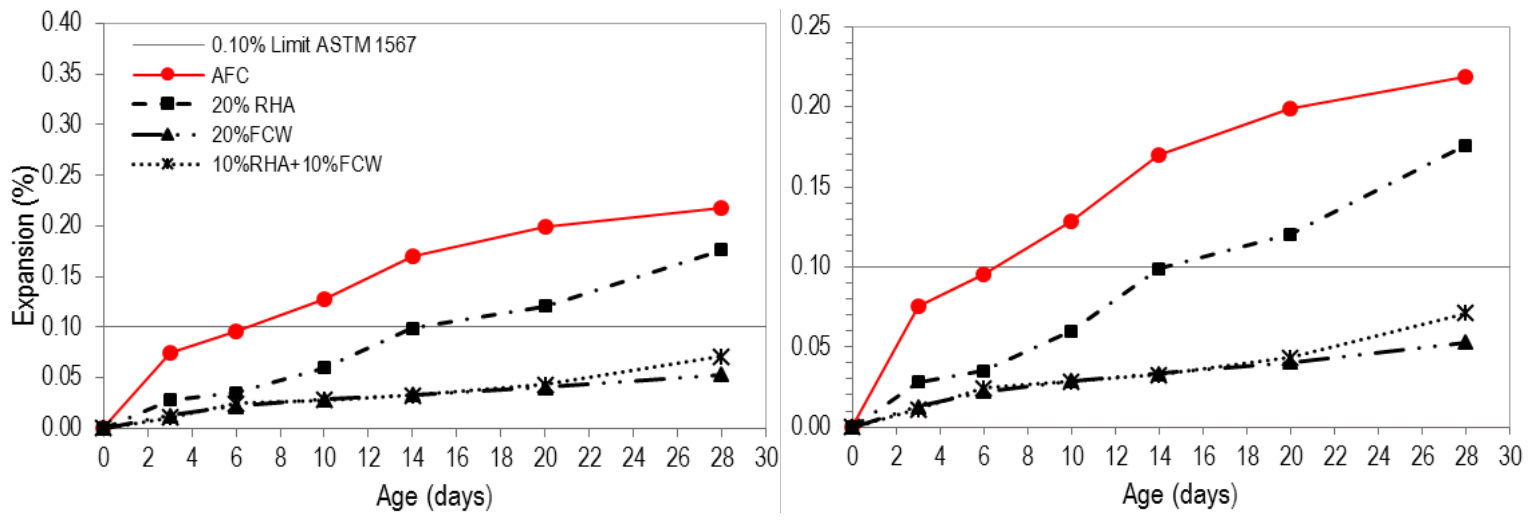


Table 3 - Standard deviation of the mixtures with AFC aggregate

\begin{tabular}{l|c|c|c|c|c|c|c}
\hline \multicolumn{1}{c|}{ Mix/Age (days) } & $\mathbf{0}$ & $\mathbf{3}$ & $\mathbf{6}$ & $\mathbf{1 0}$ & $\mathbf{1 4}$ & $\mathbf{2 0}$ & $\mathbf{2 8}$ \\
\hline $20 \%$ RHA & 0.000 & 0.000 & 0.001 & 0.001 & 0.005 & 0.002 & 0.008 \\
$20 \%$ FCW & 0.000 & 0.001 & 0.002 & 0.002 & 0.002 & 0.004 & 0.006 \\
$10 \%$ RHA + 10\% FCW & 0.000 & 0.001 & 0.003 & 0.003 & 0.005 & 0.005 & 0.009 \\
$20 \%$ RHA & 0.000 & 0.000 & 0.001 & 0.001 & 0.005 & 0.002 & 0.008 \\
\hline
\end{tabular}

It is commonly supposed that the reduction of expansions associated with pozzolanic materials is associated to the fact that they consume calcium hydroxide and alkaline hydroxides from the cement paste, forming secondary calcium silicate hydrate. Thus, due to the reduction of the pores of the concrete by filling them with the products of the pozzolanic reaction, there is also a reduction in the quantity of alkali available in the pore solution to react with the reactive minerals of the aggregate (GLASSER, 1992).

However, the reduction of the expansions is not restricted to the fact that the materials are pozzolanic, because, as seen, both of the studied materials are pozzolanic and still exhibited very different expansion behaviors. Samples containing RHA that presented higher pozzolanic activity also showed higher percentages of expansion. Samples containing FCW, on the other hand, which presented lower pozzolanic activity, showed the smallest expansions. Therefore, it is clear that only the pozzolanic reaction formed by the mineral admixtures is not sufficient to justify the AAR mitigation. There are other specific factors that should be analyzed separately in each type of pozzolanic material. One of these factors may be related to their chemical composition. It appears that the content of alumina present in the silicoaluminate pozzolanic material, as is the case of FCW, is in fact a determining factor to mitigate the AAR, since it is not present in large quantities in the RHA. This fact can be supported by Chappex and Scrivener (2012b), who link the benefit of alumina to its ability to inhibit the dissolution of silica present in the reactive minerals of the aggregates. According to the authors, the incorporation of alumina in the reactive silica structure of the aggregate, forming a type of zeolite, prevents or limits the contact of the alkalis with the reactive silica (CHAPPEX; SCRIVENER, 2013; RAJABIPOUR et al., 2015).

Figure 7 shows the average expansions obtained from samples with $20 \%$ cement substitution by RHA, FCW and RHA + FCW with the innocuous aggregate (AVR) after 28 days of submersion in $\mathrm{NaOH}$ solution. Table 4 presents the standard deviation for the three specimens produced for each mixture.
Given that this is an innocuous aggregate, it tends not to react with the alkali of the cement, since it does not contain reactive silica. This silica is considered reactive when present in amorphous form or presents deformations in its structure. Thus, based on the petrographic analysis and the accelerated test of the mortar bars, it was verified that the AVR does not present reactive potential. Nevertheless, mixtures containing the pozzolanic materials were subjected to the accelerated expasion test in order to evaluate the possibility of ASR occurence.

The FCW and RHA + FCW samples presented similar expansion values (Figure 7), remaining well below the expansion limit of $0.10 \%$ established by C-1567 (AMERICAN..., 2013). Both blends containing FCW reached a maximum expansion of $0.03 \%$, at 28 days of the test. In contrast, samples containing 20\% RHA have developed expansion, even without the presence of the reactive aggregate. At 14 days, they expanded by $0.09 \%$, and continued to grow until the age of 28 days, reaching $0.14 \%$ and exceeding the standardized limit.

Samples containing RHA, under such accelerated conditions, may form expansive products. This can be explained by the agglomeration of silica particles, which act as a reactive aggregate composed of amorphous silica, reacting with the alkali present in the pore solution (DIAMOND; SAHU; THAULOW, 2004; MASS; IDEKER; JUENGER, 2007). Cyr, Rivard and Labrecque (2009) observe that a material containing silica can act as a pozzolan or as a reactive aggregate, depending on the size of the particles (agglomerates). Thus, it is believed that the expansions observed in samples containing 20\% RHA and AVR are related to the chemical composition of the pozzolanic material, which presents almost 95\% of silica in its composition, as shown in Table 1. The effect of RHA on ASR can be reduced by the use of superplasticizing admixtures, which tend to disperse the particles, avoiding the agglomerates.

\section{Axial compressive strength}

Figure 8 shows the compressive strength of the reference samples, containing RHA, FCW and both materials combined, produced with the AFC 
aggregate. It can be observed that the mortars fabricated with RHA presented higher compressive strength as compared to the reference mortar in the three ages evaluated. While the reference mortars reached an average strength of $58.0 \mathrm{MPa}$ at 28 days, the mortars with 20\% RHA obtained an average strength of $60.7 \mathrm{MPa}$. Although the samples with RHA have not presented satisfactory performance in the AAR test, it can be emphasized that they contribute to compressive strength growth. These benefits can be explained due to its high pozzolanic activity, the fineness of the RHA and the consequent reduction of concrete porosity.

The FCW showed a decrease in compressive strength compared to the reference sample. On average, this decrease in compressive strength of mortars containing FCW, compared to the control mix at 28 days, was $10.8 \%$. Possibly, this decrease of compressive strength is associated to the fixation of the w/c ratio, since the mixtures were quite dry the molding was more difficult. It should be noted that in the pozzolanic activity test, the consistency level of the mortars was adjusted with the incorporation of a superplasticizer, and the samples containing 25\% FCW showed greater compressive strength than the reference samples. Therefore, the loss of workability due to the fixation of the w/c ratio may justify the decrease in compressive strength, since the samples may have presented a large volume of pores. In addition, the particle size may have been influenced in the packaging of the blend and in the formation of the pozzolanic reaction. Gonçalves et al. (2009) also observed a reduction in compressive strength at replacement contents above $20 \%$, possibly due to the nonformation of secondary C-S-H, but only by the physical (filer) effect.

The mortar containing 10\% RHA + 10\% FCW presented higher compressive strength than the FCW mixture throughout the ages tested, and initially higher compressive strength than the reference samples as well. However, this increase was surpassed by reference samples at 28 days. In this way, a slight decrease of approximately $3 \%$ in compressive strength was observed at the age of 63 days.

\section{Conclusions}

FCW is a calcined clay, considered a pozzolanic silico-aluminate material, and has been shown to be effective in reducing AAR expansions, always remaining below the limit established by standards until the end of the test. It is supposed that the positive effect of FCW in the mitigation of AAR is related to its chemical composition, especially to the alumina content present. In relation to the compressive strength, the FCW presented lower performance when compared to the control samples. However, this decrease of strength may be related to the difficulty of molding the specimens, due to the fixed w/c ratio.

Figure 7 - Expansions of the mortar bars fabricated with pozzolans and the innocuous aggregate (AVR)
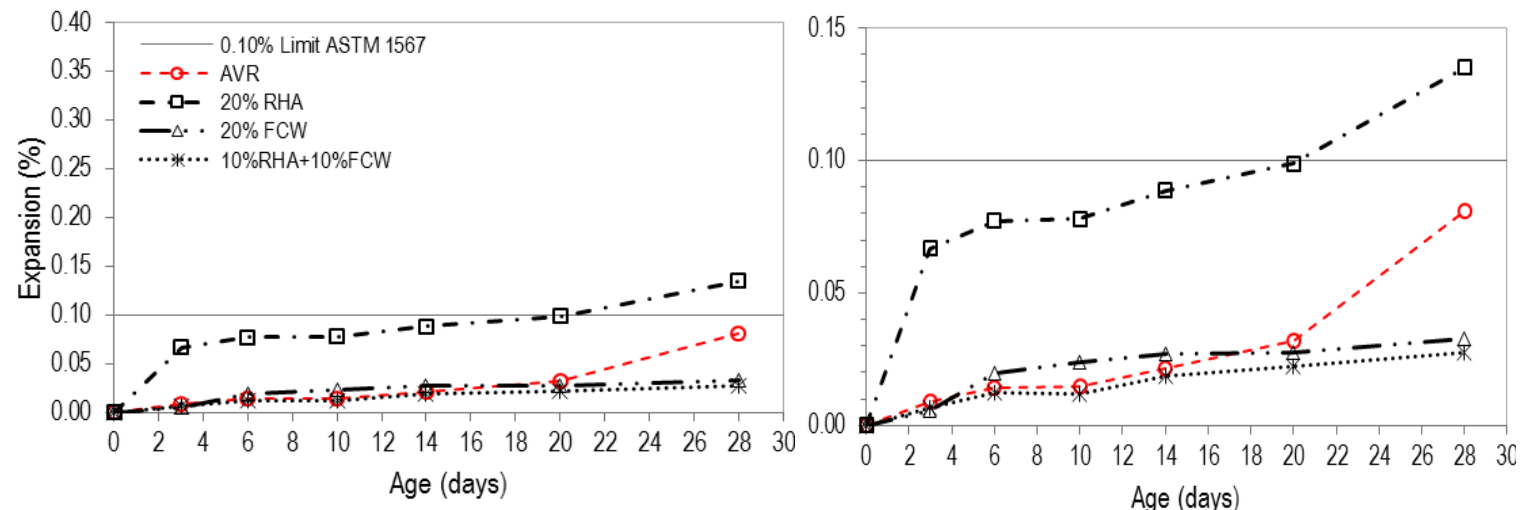

Table 4 - Standard deviation of the mixtures with AVR aggregate

\begin{tabular}{l|c|c|c|c|c|c|c}
\hline \multicolumn{1}{c}{ Mix/Age (days) } & $\mathbf{0}$ & $\mathbf{3}$ & $\mathbf{6}$ & $\mathbf{1 0}$ & $\mathbf{1 4}$ & $\mathbf{2 0}$ & $\mathbf{2 8}$ \\
\hline $20 \%$ RHA & 0.000 & 0.004 & 0.004 & 0.005 & 0.008 & 0.003 & 0.004 \\
$20 \%$ FCW & 0.000 & 0.002 & 0.001 & 0.002 & 0.002 & 0.003 & 0.003 \\
$10 \%$ RHA + 10\% FCW & 0.000 & 0.000 & 0.001 & 0.000 & 0.000 & 0.001 & 0.001 \\
$20 \%$ RHA & 0.000 & 0.004 & 0.004 & 0.005 & 0.008 & 0.003 & 0.004 \\
\hline
\end{tabular}


Figure 8 - Axial compressive strength

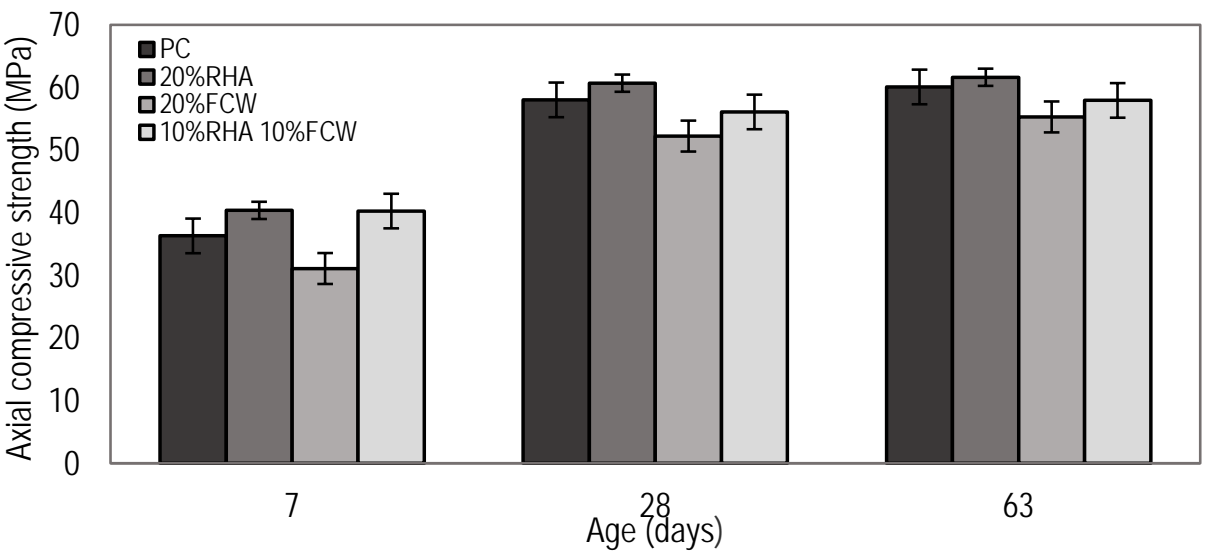

Samples containing RHA showed good performance regarding compressive strength, surpassing the compressive strength of the reference samples. However, in the AAR experiments, RHA seems to increase expansion reactions, even when using an innocuous aggregate. The fact that RHA is deleterious by AAR seems to be related to its chemical composition, since it is composed basically of silica, and particle agglomeration - silica particles present in the RHA can agglomerate and act as a reactive aggregate, reacting with the alkalis of the cement and initiating ASR.

Based on the results obtained in the mortar bar tests produced with AFC aggregate, it can be concluded that the pozzolanic materials tested here, when studied separately, have different behavioral tendencies. RHA contributes positively to the compressive strength, but it does not mitigate the development of the AAR. In the analysis of FCW, a reduction in the compressive strength is verified, however, the AAR is significantly mitigated. Nevertheless, when the two materials were used in a combined manner, it can be verified that the positive effects of each of the pozzolans contribute to the improvement of the studied properties, canceling out the negative effect observed in the use of each material alone. Thus, it can be concluded that the RHA can meet the compressive strength requirements not reached by the FCW, while the FCW can alleviate the deleterious effects of the RHA in the AAR.

\section{References}

ABBAS, S.; KAZMI, S. M. S.; MUNIR, M. J. Potential of Rice Husk Ash For Mitigating the Alkali-Silica Reaction in Mortar Bars Incorporating Reactive Aggregates. Construction and Building Materials, v. 132, p. 61-70, 2017.
ADORNO, C. dos S. et al. Efects of the Addition of Red Ceramic, Limestone Fller and Rice Husk Ash in Alkali Silica Reaction. Journal of Building Pathology and Rehabilitation, v. 3, p. 1-11, 2018.

AFSHINNIA, K.; POURSAEE, A. The Potential of Ground Clay Brick to Mitigate Alkali-Silica Reaction in Mortar Prepared With Highly Reactive Aggregate. Construction and Building Materials, v. 95, p. 164-170, 2015.

AFSHINNIA, K.; RANGARAJU, P. R. Efficiency of Ternary Blends Containing Fine Glass Powder in Mitigating Alkali-Silica Reaction.

Construction and Building Materials, v. 100, p. 234-245, 2015.

\section{AMERICAN SOCIETY FOR TESTING AND}

MATERIALS. ASTM C-1260: standard test method for potential alkali reactivity of aggregates (Mortar-Bar Method). West Conshohocken, 2014.

AMERICAN SOCIETY FOR TESTING AND MATERIALS. ASTM C-1567: standard test method for determining the potential alkali-silica reactivity of combinations of cementitious materials and aggregate (accelerated mortar-bar method). West Conshohocken, 2013.

AMORIM, L. V.; PEREIRA, A. S. G.; NEVES, Gelmires de Araújo; FERREIRA, Herbes Carlos Reciclagem de Rejeitos de Cerâmica Vermelha e da Construção Civil para Obtenção de Aglomerantes Alternativos. Cerâmica Industrial, v. 5, p. 35-46, 2000.

\section{ASSOCIAÇÃO BRASILEIRA DE NORMAS} TÉCNICAS. NBR 5752: Materiais pozolânicos Determinação do índice de desempenho com cimento Portland aos 28 dias. Rio de Janeiro, 2014. 
ASSOCIAÇÃO BRASILEIRA DE NORMAS TÉCNICAS. NBR 7215: Cimento Portland Determinação da resistência à compressão. Rio de Janeiro, 1996.

\section{ASSOCIAÇÃO BRASILEIRA DE NORMAS} TÉCNICAS. NBR 12653: Materiais pozolânicos Requisitos. Rio de Janeiro, 2014.

CHAPPEX, T.; SCRIVENER, K. Alkali Fixation of C-S-H in Blended Cement Pastes and Its Relation to Alkali Silica Reaction. Cement and Concrete Research, v. 42, p. 1049-1054, 2012 a.

CHAPPEX, T.; SCRIVENER, K. The Influence of Aluminium on the Dissolution of Amorphous Silica and Its Relation to Alkali Silica Reaction. Cement and Concrete Research, v. 42, p. 16451649, 2012b.

CHAPPEX, T.; SCRIVENER, K. The Effect of Aluminum in Solution on the Dissolution of Amorphous Silica and its Relation to Cementitious Systems. Journal of the American Ceramic Society, v. 96, n. 2, p. 592-597, 2013.

CORDEIRO, G. C.; DÉSIR, J. M. Potencial de Argila Caulinítica de Campos dos Goytacazes, RJ, na Produção de Pozolana Para Concreto de Alta Resistência. Cerâmica, São Paulo, v. 56, p. 71-76, 2010.

CYR, M.; RIVARD, P.; LABRECQUE, F. Reduction of ASR-Expansion Using Powders Ground From Various Sources of Reactive Aggregates. Cement and Concrete Composities, v. 31, p. 438-446, 2009.

DAL MOLIN, D. C. Técnicas Experimentais Para o Estudo da Microestrutura. In: ISAIA, G. C. (Org.). Materiais de Construção Civil e Princípios de Ciência e Engenharia de Materiais. São Paulo: IBRACON, 2007.

DEMIR, I.; YAPRAK, H.; SIMSEK, O. Performance of Cement Mortars Replaced by Ground Waste brick in Different Aggressive Conditions. Ceramics - Silikáty, v. 55, p. 268275, 2011.

DIAMOND, S.; SAHU, S.; THAULOW, N. Reaction Products of Densified Silica Fume Agglomerates in Concrete. Cement and Concrete Research, v. 34, p. 1625-1632, 2004.

GLASSER, F. P. Chemistry of the AlkaliAggregate Reaction. In: SWAMY, R. N. (Ed.). The Alkali-Silica Reaction in Concrete. Glasgow: Blackie and Son, 1992.

GONÇALVES, J. P. et al. Performance Evaluation of Cement Mortars Modified With Metakaolin or Ground Brick. Construction and Building Materials, v. 23, p. 1971-1979, 2009.
HAMAB, M. A.; KHATTAB, I. A. Effect of the Combustion Process on the Structure of Rice Hull Sílica. Thermochimica Acta, v. 48, p. 343-349, 1981.

HASPARYK, N. P. Investigação dos Mecanismos da Reação Álcali-Agregado: efeito da cinza de casca de arroz e da sílica ativa. 1999. Goiânia, 1999. 257 f. Dissertação (Mestrado em Engenharia Civil) - Curso de Mestrado em Engenharia Civil, Universidade Federal de Goiás, Goiânia, 1999.

JAMIL, M. et al. Pozzolanic Contribution of Rice Husk Ash in Cementitious System. Construction and Building Materials, v. 47, p. 588-593, 2013.

KAZMIERCZAK, C. de S. Produtos de Cerâmica Vermelha. In: ISAIA, G. C. Materiais de Construção Civil e Princípios de Ciência e Engenharia de Materiais. São Paulo: IBRACON, 2010.

KEPPERT, M. et al. Rational Design of Cement Composites Containing Pozzolanic Additions. Construction and Building Materials, v. 148, p. 411-418, 2017.

LE, H. T.; SIEWERT, K.; LUDWIG, H. M. Alkali Silica Reaction in Mortar Formulated From SelfCompacting High Performance CONCRETE Containing Rice Husk Ash. Construction and Building Materials, v. 88, p. 10-19, 2015.

MADANDOUST, R. et al. Mechanical Properties and Durability Assessment of Rice Husk Ash Concrete. Biosystems Engineering, v. 110, p. 144-152, 2011.

MASS, A. J.; IDEKER, J. H.; JUENGER, M. C. G. Alkali Silica Reactivity of Agglomerated Silica Fume. Cement and Concrete Research, v. 37, p. 166-174, 2007.

MUNHOZ, F. A. da C. Efeito de Adições Ativas na Mitigação das Reações Álcali-Sílica e ÁlcaliSilicato. São Paulo, 2007. 166 f. Dissertação (Mestrado em Engenharia) - Escola Politécnica, Universidade de São Paulo, São Paulo, 2007.

PEREIRA-DE-OLIVEIRA, L. A.; CASTROGOMES, J. P.; SANTOS, P. M. S. The Potential Pozzolanic Activity of Glass and Red-Clay Ceramic Waste as Cement Mortars Componentes. Construction and Building Materials, v. 31, p. 197-203, 2012.

POUEY, M. T. F. Beneficiamento da Cinza de Casca de Arroz Residual Com Vistas à Produção de Cimento Composto e/ou Pozolânico. Porto Alegre, 2006. 320 f. Tese (Doutorado em Engenharia) - Programa de PósGraduação em Engenharia Civil, Universidade Federal do Rio Grande do Sul, Porto Alegre, 2006. 
PRISZKULNIK, S. Inspeção e Diagnóstico de Estruturas de Concreto com Problemas de Reação Álcali-Agregado. In: ISAIA, Geraldo Cechella. (Org.). Concreto: Ensino, Pesquisa e Realizações. São Paulo: IBRACON, 2005. p. 1017-1070.

RAJABIPOUR, F. et al. Alkali-Silica Reaction: current understanding of the reaction mechanisms and the knowledge gaps. Cement and Concrete Research, v. 76, p. 130-146, 2015.

ROJAS, M. I. S. et al. Durability of Blended Cement Pastes Containing Ceramic Waste as a Pozzolanic Addition. Journal of the American Ceramic Society, v. 97, p. 1543-1551, 2014.

SHARMA, D. K.; SHARMA, R. Influence of Rice Husk Ash and Rice Tiller Ash Along With Chromate Reducing Agents on Strength and Hydration Properties of Ordinary Portland Cement. Construction and Building Materials, v. 169, p. 843-850, 2018.

SILVEIRA, A. A. Contribuição ao Estudo do Efeito da Incorporação de Cinza de Casca de Arroz em Concretos Submetidos à Reação Álcali-Agregado. Porto Alegre, 2007. 226 f. Tese (Doutorado em Engenharia) - Programa de PósGraduação em Engenharia Civil, Universidade Federal do Rio Grande do Sul, Porto Alegre, 2007.
SOUZA, G. P. et al. Mineralogical Analysis of Brazilian Ceramic Sedimentary Clays Used in Red Ceramic. Cerâmica, v. 51, n. 320, p. 382-387, 2005.

TURANLI, L.; BEKTAS, F.; MONTEIRO, P. J. M. Use of Ground Clay Brick as a Pozzolanic Material to Reduce the Alkali-Silica Reaction. Cement and Concrete Research, v. 23, p. 15391542, 2003.

ZAIN, M. F. M. et al. Production of Rice Husk Ash For Use in Concrete as a Supplementary Cementitious Material. Construction and building materials, v. 25, p. 798-805, 2011.

\section{Acknowledgements}

This study was financed in part by the Coordenação de Aperfeiçoamento de Pessoal de Nível Superior Brazil (CAPES) - Finance Code 001. The authors wish to acknowledge also the support of Brazilian agencies Fundação de Amparo à Pesquisa do Estado do Rio Grande do Sul (FAPERGS) and Conselho Nacional de Pesquisa (CNPq).

Patrícia Guillante

Programa de Pós-Graduação em Engenharia Civil | Universidade do Vale do Rio do Sinos | Av. Unisinos, 950, Cristo Rei | São Leopoldo - RS - Brasil | CEP 93022-750 | Tel.: (51) 3591-1264 | Email: pguillante@gmail.com

Aguida Gomes de Abreu

Programa de Pós-Graduação em Engenharia Civil | Universidade do Vale do Rio do Sinos | E-mail: aguidaabreu@gmail.com

Marlova Piva Kulakowski

Programa de Pós-Graduação em Engenharia Civil | Universidade do Vale do Rio do Sinos | E-mail: marlovak@unisinos.br

Maurício Mancio

Programa de Pós-Graduação em Engenharia Civil | Universidade do Vale do Rio do Sinos | E-mail: mancio@unisinos.br

Claudio de Souza Kazmierczak

Programa de Pós-Graduação em Engenharia Civil | Universidade do Vale do Rio do Sinos | E-mail: claudiok@unisinos.br

Revista Ambiente Construído

Associação Nacional de Tecnologia do Ambiente Construído

Av. Osvaldo Aranha, 99 - 3o andar, Centro

Porto Alegre - RS - Brasil CEP $90035-190$

Telefone: +55 (51) 3308-4084

Fax: +55 (51) 3308-4054

www. seer. ufrgs. br/ ambienteconstruido

E-mail: ambienteconstruido@ufrgs.br 